\title{
Analysis of Higher Order Thinking Skills in English Lesson Plans
}

\section{MDA Hemas ${ }^{1}$, NKWedhanti $^{2}$, PAKJuniarta $^{3}$}

1,2,3 Pendidikan Bahasa Inggris, Universitas Pendidikan Ganesha, Singaraja, Indonesia

\section{ART ICLE INFO}

Article history:

Received July 11, 2021

Revised July 13, 2021

Accepted September 23, 2021

Available online October 25, 2021

\section{Kata Kunci:}

Keterampilan Berpikir Tingkat Tinggi (HOTS), Rencana Pelajaran

Keywords:

Higher Order Thinking Skills (HOTS), Lesson Plans

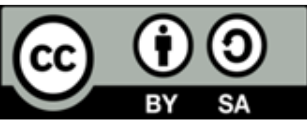

This is an open access article under the CC BY-SA license.

Copyright $(2021$ by Author. Published by Universitas Pendidikan Ganesh

\begin{abstract}
A B S T RA K
Sejalan dengan perkembangan pendidikan abad 21 yang saat ini menekankan pada berpikir kritis, analisis masalah, pemecahan masalah, pengambilan keputusan, dan penciptaan sesuatu yang baru. Hal ini menuntut guru untuk menggunakan paradigma baru dalam merancang RPP yang menunjukkan Higher Order Thinking Skills (HOTS). Pelaksanaannya tidak berjalan sesuai rencana. Penelitian ini bertujuan untuk mengidentifikasi isi RPP terkait indikator Higher Order Thinking Skill (HOTS). Desain penelitian kualitatif dengan studi dokumen digunakan untuk menganalisis data. Data diperoleh secara kualitatif dengan melakukan observasi, analisis dokumen, dan wawancara. Hasil penelitian menunjukkan bahwa Higher Order Thinking Skills (HOTS) tidak tercantum dalam keseluruhan RPP tetapi hanya terdapat di beberapa bagian. Aspek terintegrasi HOTS adalah kompetensi dasar dan indikator. Hasil ini berimplikasi pada guru bahasa Inggris untuk mengembangkan penerapan Higher Order Thinking (HOTS) dalam isi RPP.
\end{abstract}

\section{A B S T R A C T}

In line with the development of 21 st century education which currently emphasizes critical thinking, problem analysis, problem solving, decision making, and the creation of something new. It requires teachers to use a new paradigm in designing lesson plans that demonstrate Higher Order Thinking Skills (HOTS). The implementation did not go according to plan. This study aims to identify the content of lesson plans related to Higher Order Thinking Skill (HOTS) indicators. A qualitative research design with a document study was used to analyze the data. Data obtained qualitatively by conducting observations, document analysis, and interviews. The results showed that Higher Order Thinking Skills (HOTS) were not listed in the entire lesson plan but were only found in some parts. The integrated aspects of HOTS are basic competencies and indicators. These results have implications for English teachers to develop the application of Higher Order Thinking (HOTS) in the content of lesson plans.

\section{INTRODUCTION}

Vocational education is one of the educations that builds work competence (Sudira \& Juwanto, 2019). Vocational education is one of the educational pathways to prepare students to get jobs through mastering skills relevant to the world of work (Fitriyanto \& Pardjono, 2019). Vocational education can help develop optimal, quality, and competitive human resources (Gunawan et al., 2021). The existence of vocational education is closely related to the social development of the workforce and produces quality workers (Hamid et al., 2017). Vocational learning must encourage students to be creative and innovative, think critically to solve problems and have the ability to communicate and collaborate (Hidayati \& Wagiran, 2020). So, in other words, vocational education is an education that provides human resources who are ready to work. Vocational education must produce human resources who can compete in the era of the industrial revolution 4.0 and have 21st-century capabilities. 21st-century abilities include communication, collaboration, creativity, and critical thinking skills. According to skills (Bialik \& Fadel, 2015; Erd ogan, 2019; Pardede, 2020; Perron et al., 2021), 4C skills play an important role in learning because they can help teachers face the future.

Among the four existing skills, critical thinking is one of the essential skills in 21st-century education that students need to master. Critical thinking ability is the ability to analyze facts, convey ideas, defend opinions, make comparisons, draw conclusions and evaluate the arguments given, and the ability to solve problems (Pramestika et al., 2020; Rati \& Rediani, 2020). Critical thinking is a person's cognitive 
ability to state something with confidence because it is based on logical reasons and strong evidence (Meilana et al., 2020). Critical thinking skills allow students to use information sources to produce solutions and provide opportunities for students to build relationships (Polat \& Aydın, 2020). The ability to think critically is one of the important learning outcomes in education (Hart et al., 2021; Yu et al., 2021). Critical thinking skills are related to the ability of students to deal with everyday problems (Odebiyi \& Odebiyi, 2021). An innovative learning process is needed to allow students to develop critical thinking skills (Seibert, 2020; Silberman et al., 2021). In this case, the teacher's role is very important to create learning that familiarizes students to think critically.

One of the teacher's roles is in making lesson plans. The lesson plan is a very important component in the learning process. A lesson plan is a written text compiled based on a systematic analysis of student development to make learning more effective and efficient by the demands of students and society (Sumantri, 2015). A lesson plan is a learning plan whose development refers to a certain basic competency in the curriculum or syllabus (Ihsan \& Jamal, 2017). Developing a Lesson Plan following the curriculum will make the Lesson Plan more effective and efficient. A good lesson plan must be a lesson plan consisting of the following aspects; (1) The identity of the school or the name of the education unit; (2) Identity of learning content/theme/sub-theme; (3) Class/semester; (4) Subject matter; (5) Time allocation; (6) learning objectives; (7) Basic competencies and indicators of competency achievement; (8) Learning materials; (9) learning methods; (10) learning media; (11) Learning resources; (12) Learning steps which include opening, core and closing activities; and (13) Assessment of learning outcomes. Designing a lesson well will implement learning avoid mistakes. Therefore, the learning design must be adjusted to the demands of the curriculum. As it is today, the curriculum demands are higher order thinking skills. Drawing up a lesson plan with indicators that focus on higher-order thinking skills will familiarize students with learning by developing critical thinking skills, which has an impact on HOTS thinking skills.

Several studies have been carried out relating to HOTS abilities, research which states that there is a significant increase in students' higher order thinking skills after learning mathematics with the help of HOTS-based worksheets (Purwasi \& Fitiyana, 2020). Research which states that the results of data analysis are as follows: 1) HOTS assessment is a question or task that has the characteristics: assessing students' ability to analyze, evaluate, and create based on contextual problems, and not routine (not familiar); 2) the steps for compiling HOTS items are: a) analyzing Basic Competencies that HOTS items can be made, b) compiling a blueprint for HOTS items, c) writing down questions on question cards, d) determining answer keys (multiple choice questions form) or compiling rubrics/guidelines for assessment (essay form), e) conducting qualitative analysis, and f) conducting quantitative analysis; 3) the advantages of HOTS assessment are: a) Increasing students' learning motivation and b) improving learning outcomes. and f) conduct quantitative analysis; 3) the advantages of HOTS assessment are: a) Increasing students' learning motivation and b) improving learning outcomes. and f) conduct quantitative analysis; 3 ) the advantages of HOTS assessment are: a) Increasing students' learning motivation and b) improving learning outcomes (Widana, 2017). Research shows that the use of HOTS-based worksheets has a positive and significant effect on learning motivation, but the use of HOTS-based worksheets does not have a positive and significant effect on science learning outcomes (Karsono, 2017; Purnama \& Nurdianingsih, 2019). Based on the above phenomena and the importance of integrating higher order thinking skills in the classroom for students, this study aims to explore higher order thinking skills and processes in the teacher lesson plan at SMK Negeri 3 Singaraja English teachers integrate these skills and abilities. Critical thinking processes in their lesson plans.

\section{METHOD}

The type of research conducted is qualitative research. Through qualitative methods, in-depth understanding and explanation of the meaning, reality, and related facts can be obtained. Understanding qualitative research argues that qualitative research is descriptive, and the data collected is more in the form of words or pictures than numbers. This research uses descriptive analysis. This means that researchers narratively describe the data. One of the characteristics of the qualitative method is the natural setting where face-to-face interactions from time to time to obtain information related to this research use descriptive qualitative methods to find answers to research questions. So, this research uses qualitative. A method describes and identifies how teachers include High Order Thinking Skills in the English Lesson Plan at SMK Negeri 3 Singaraja. This research was conducted at SMK Negeri 3 Singaraja, located in Banyuning, Kecamatan Buleleng, Kabupaten Buleleng. It was chosen because SMK Negeri 3 Singaraja is one of the SMKs in Buleleng that has implemented Higher Order Thinking Skills. The subject of this research is the twelfth grade English teacher at SMK 3 Singaraja, namely Yulistini, S.Pd. In addition, the twelfth grade teacher document (English Lesson Plan) at SMK Negeri 3 Singaraja was also used as the subject of this research. The 
object of this research is the higher order thinking skills and processes identified in the Lesson Plan. Data collection methods required certain techniques. The researcher used several data collection techniques in this study, namely (1) Observation. The observation was carried out to ask permission to research the analysis of the existence of higher-order thinking abilities and processes in the twelfth grade lesson plan at SMK Negeri 3 Singaraja. First, the researcher determined a data collection permit at SMK Negeri 3 Singaraja from the Faculty of Language and Arts, Ganesha University of Education. Furthermore, the researchers received a letter of permission to conduct research from the principal of SMK Negeri 3 Singaraja. (2) Documentation is a way of collecting data that produces important notes related to the problem being studied, valid and not based on estimates to obtain complete data. (3) interviews were used to collect data by asking and answering English teachers at SMK Negeri 3 Singaraja.

Interviews were used to obtain data on teachers who developed higher order thinking skills in the Lesson Plan. In addition, interviews were also conducted to obtain in-depth information about the problem. Interviews were also used to find additional and relevant information that was not obtained through the analysis process, such as educational background, teaching experience, how to prepare Lesson Plans, etc. There are four research instruments: (1) Researchers as a key instrument to collect data. It means that the researcher is the main instrument in this study. Researchers decide and observe phenomena in the field. (2) Documentation, the documents collected by the researcher are: Lesson Plan and its attachments in the form of (a) types/techniques of assessment, (b) forms of assessment instruments and instruments including; knowledge assessment, skills assessment, (c) assessment guidelines, (d) remedial, and (e) enrichment. (3) Interview Guidelines, the researcher uses interview techniques to obtain data according to the data obtained. The researcher conducted a direct dialogue with the research object, namely the English teacher who teaches in the twelfth grade of SMK Negeri 3 Singaraja. The guidelines used by researchers are questions. Researchers have made structured questions that make it easier for researchers during interviews. Interviews were conducted to find out the Lesson Plan, which contains the HOTS domain. (4) Checklist, namely the observation checklist used by researchers to obtain data based on the classification of types of communication strategies. The observations obtained data from transcription and classification, then checked on the observation checklist. This checklist can be obtained through a customized higher order thinking skills instrument checklist based on the blueprint for analyzing research instrument documents and lesson plans. Data were analyzed through the following steps: (1) Data collection, (2) Identification, (3) Classification, (4) Interpretation. To find out that the Lesson Plan design made by the English teacher already has indicators of higher-order thinking skills, the researcher analyzed the Lesson Plan design on the basic competency components and the Lesson Plan design indicator that contains indicators of higher-order thinking skills is the Lesson Plan which includes basic competencies. Components, indicators, contain higher order thinking skills at the analyzing, evaluating, and creating level. In addition to analyzing the Lesson Plan components that contain indicators of higher-order thinking skills, the Lesson Plan is also analyzed for conformity with the provisions contained in Permendikbud no. 103 of 2014

\section{RESULT AND DISCUSSION}

\section{Result}

The results showed that the characteristics of higher order thinking skills were identified in the Lesson Plan for the twelfth grade English teacher. Higher order thinking skills are included in the components of the lesson plan. The lesson plan includes subject identity, core competencies, basic competencies, indicators, learning objectives, learning resources, learning materials, learning media, learning strategies, learning activities, and assessments. Basic competence refers to the content or competence consisting of attitudes, knowledge, and skills that must be mastered by students originating from core competencies. These competencies are developed after paying attention to student characteristics, initial abilities, and characteristics of subjects. Based on the four Lesson Plans, there are eight basic competencies developed in the Lesson Plan: (1) Analyzing the structure of the text and linguistic elements to carry out the social functions of factual scientific texts by stating and asking questions about factual scientific texts, (2) Capturing meaning in scientific texts factual, oral and written, (3) Distinguishing social functions, text structure, and linguistic elements of several oral and written news texts by giving and asking for information related to simple news from newspapers/radio/TV, according to the context of their use, (4) Capturing contextual meaning related to social functions, text structure, and linguistic elements of the text of oral and written news items, in the form of simple newspaper/radio/TV news, (5) Analyzing social functions, text structures, and linguistic elements of special texts, spoken and written, in the form of a job application letter, (6) Prepare a job application letter, by paying mentioning social functions, text structure, and policy elements correct language and in accordance with the context, (7) Analyzing social 
functions, text structure, and linguistic elements in expressions that initiate the delivery of surprising news or information along with their responses, according to the context of their use, (8) Composing spoken and written texts to express and respond to expressions that initiate the delivery of surprising news or information by paying attention to social functions, text structures, and linguistic elements that are correct and in context. It can be said that of the 8 basic competencies, the operational word reflects the HOTS ability. HOTS ability can also be seen from the indicators made in operational verbs. Lesson Plan indicators use various operational verbs such as indicate, identify, create, create, retell, etc. Based on the four Lesson Plans, there are variations in the number of indicators for each basic competency. There are about four indicators developed for the knowledge aspect: (1) Identifying the structure of the text and linguistic elements to carry out the social function of factual scientific texts, (2) Identifying the text structure of oral and written news items by giving and asking for information related to simple news, (3) Identify social functions, text structures, and linguistic elements of job application texts, (4) Identify social functions, text structures, and linguistic elements of surprised expression texts. As for the skills aspect, nine indicators were developed; (1) Analyzing the text structure and linguistic elements to carry out the social functions of factual scientific texts, (2) Compiling simple written factual scientific texts, (3) Capturing contextual meanings related to social functions, text structures, and linguistic elements of oral news texts and written items, (4) Composing oral and written news texts, (5) Communicating oral and written news texts, (6) Compiling job application letters, (7) Presenting job applications, (8) Composing simple dialogues about surprising expressions, (9) Presenting dialog. From the interview results, it is known that the English teacher has mastered the preparation of lesson plans well and it is also explained how lesson plans define higher order thinking skills. So, the ability of Higher Order Thinking Skills is seen from the operational words in the basic competencies and indicators, if they contain operational verbs to create, analyze, compose, etc. Included in the realm of Higher Order Thinking Skills. Included in the operational verbs of Higher Order Thinking Skills are operational verbs C4, C5, and C6. This means that English teachers always design basic competencies and indicators that contain higher-order thinking skills.

\section{Discussion}

The study results indicate that the lesson plan used by the teacher in learning English has included the HOTS ability. It can be seen in the basic competencies and indicators that already have operational words at the cognitive level C4, C5 and C6. HOTS ability is one of the most important skills in the learning process. Higher order thinking skills can make an individual able to interpret, analyze or manipulate the information obtained (Noprinda \& Soleh, 2019; Pratiwi, 2017). Developing the HOTS ability requires the teacher to provide a stimulus that is following the HOTS ability through the provision of problems (Nisa \& Pahlevi, 2021; Wulandari et al., 2020). HOTS problems are characterized by an assessment based on real problems in students' daily lives (Khotimah \& Sari, 2020). Integrating HOTS learning will make the learning process more fun and encourage active student involvement, which encourages students to know, but also to do, to be, and to live together, as well as holistic and authentic (Syudirman \& Saputra, 2020). Creating such learning, of course, the components of the lesson plans that are designed must also be adjusted to the ability of HOTS. HOTS ability indicators are problem solving, decision making, critical thinking, and creative thinking (Dinni, 2018; Pratiwi, 2017; Rahayu et al., 2021). These indicators of HOTS capability must be stated in the form of indicators in the Lesson Plan, which will later be used as a reference in the learning process. Indicators are formulated in operational verbs that can be measured and observed to be used as basic formulation instruments.

Based on these descriptions, it can be said that the Lesson Plan that is designed must be equipped with the following aspects; (1) The identity of the school or the name of the education unit; (2) Identity of learning content/theme/sub-theme; (3) Class/semester; (4) Subject matter; (5) Time allocation; (6) learning objectives; (7) Basic competencies and indicators of competency achievement; (8) Learning materials; (9) learning methods; (10) learning media; (11) Learning resources; (12) Learning steps which include opening, core and closing activities; and (13) Assessment of learning outcomes. In addition, the RPP must also be designed according to the demands of the curriculum. RPP is a learning plan whose development refers to a certain basic competency in the curriculum or syllabus (Ihsan \& Jamal, 2017), By developing a Lesson Plan following the curriculum, it will make the Lesson Plan more effective and efficient. What was found in the lesson plans revealed that the English teacher had designed indicators in the form of operational verbs and involved aspects of attitudes, aspects of knowledge, and aspects of skills. The results of this study can provide benefits for teachers and other researchers. This research can provide additional information to teachers about higher order thinking skills in the Lesson Plan so that teachers can consider the aspects considered and include more related to higher order thinking skills to develop properly. In addition, the teacher will be able to improve and identify the elements or characteristics of higher order thinking skills contained in the Lesson Plan. By reading this research, other researchers are given insight to 
conduct topics related to this research. Other researchers can also conduct several studies that focus on certain characteristics or missing characteristics that have not been identified in this study.

\section{CONCLUSION}

Higher order thinking skills (HOTS) have been integrated into the implementation plan for English language learning. It can be seen from the basic competencies and indicators that already use operational words C4, C5 and C6. Lesson plans consisted of core competency subjects, basic competencies, indicators, learning objectives, learning materials, learning methods, learning activities, learning media, learning resources, and assessments.

\section{REFERENCES}

Bialik, M., \& Fadel, C. (2015). Skills for the 21st centuty: What should studenst learn? In Center for Curriculum Redesign (Issue May).

Dinni, H. N. (2018). HOTS ( High Order Thinking Skills ) dan Kaitannya dengan Kemampuan Literasi $\begin{array}{llll}\text { Matematika. } & \text { Prisma, } & 1, & 170-176 .\end{array}$ https://journal.unnes.ac.id/sju/index.php/prisma/article/view/19597.

Erdogan, V. (2019). Integrating 4C Skills of 21st Century into 4 Language Skills in EFL Classes Vacide Erdoğan. International Journal of Education and Research, 7(11), 113-124.

Fitriyanto, M. N., \& Pardjono, P. (2019). Factors affecting the employability skills of vocational students majoring mechanical engineering. Jurnal Pendidikan Vokasi, 9(2), 132-140. https://doi.org/10.21831/jpv.v9i2.24420.

Gunawan, A. I., Rafiati Kania, \& Widi Senalasari. (2021). Analisis Peluang Bisnis Start-Up Konsultan UMKM dari Akademisi dan Institusi Pendidikan Vokasi. Bhakti Persada, 7(1), 11-16. https://doi.org/10.31940/bp.v7i1.2328.

Hamid, M. A., Aribowo, D., \& Desmira, D. (2017). Development of learning modules of basic electronics-based problem solving in Vocational Secondary School. Jurnal Pendidikan Vokasi, 7(2), 149. https://doi.org/10.21831/jpv.v7i2.12986.

Hart, C., Da Costa, C., D’Souza, D., Kimpton, A., \& Ljbusic, J. (2021). Exploring higher education students' critical thinking skills through content analysis. Thinking Skills and Creativity, 41(May), 100877. https: //doi.org/10.1016/j.tsc.2021.100877.

Hidayati, R. M., \& Wagiran, W. (2020). Implementation of Problem-Based Learning to Improve Problemsolving Skills in Vocational High School. Jurnal Pendidikan Vokasi, 10(2), 177-187. https://doi.org/10.21831/jpv.v10i2.31210.

Ihsan, I. N., \& Jamal, M. A. (2017). Pengembangan Perangkat Pembelajaran Berorientasi Lingkungan Sekitar Bantaran Sungai Barito Untuk Melatihkan Keterampilan Proses Sains. Berkala Ilmiah Pendidikan Fisika, 5(1), 29-45.

Karsono, K. (2017). Pengaruh penggunaan LKS berbasis hots terhadap motivasi dan hasil belajar IPA siswa SMP. Jurnal Pendidikan Matematika Dan Sains, 5(1), 50-57. https://doi.org/10.21831/jpms.v5i1.13540.

Khotimah, R. P., \& Sari, M. C. (2020). Pengembangan Lembar Kerja Peserta Didik Berbasis Higher Order Thinking Skills (HOTS) Menggunakan Konteks Lingkungan. Jurnal Aksioma, 9(3). https://doi.org/10.24127/ajpm.v9i3.2909.

Meilana, S. F., Aulia, N., Zulherman, Z., \& Aji, G. B. (2020). Pengaruh Model Pembelajaran Think Pair Share (TPS) terhadap Kemampuan Berpikir Kritis di Sekolah Dasar. Jurnal Basicedu, 5(1), 218-226. https://doi.org/10.31004/basicedu.v5i1.644.

Nisa, S., \& Pahlevi, T. (2021). Pengembangan Instrument Penilaian HOTS Berbantuan Quizizz pada Mata Pelajaran Kearsipan SMK. EDUKATIF: Jurnal Ilmu Pendidikan, 3(5), 2146-2159. https://doi.org/10.31004/edukatif.v3i5.756.

Noprinda, C. T., \& Soleh, S. M. (2019). Development Of Student Worksheet Based On Higher Order Thinking Skill (Hots ). Indonesian Journal of Science and Mathematics Education, 02(2), 168-176. https://doi.org/10.24042/IJSME.V2I2.4342.

Odebiyi, O. M., \& Odebiyi, A. T. (2021). Critical thinking in social contexts: A trajectory analysis of states' K-5 social studies content standards. Journal of Social Studies Research, 45(4), 277-288. https: //doi.org/10.1016/j.jssr.2021.05.002.

Pardede, P. (2020). Integrating the 4Cs into EFL Integrated Skills Learning. Journal of English Teaching, 6(March), 71-85. https://doi.org/10.33541/jet.v6i1.190.

Perron, N. J., Pype, P., van Nuland, M., Bujnowska-Fedak, M. M., Dohms, M., Essers, G., Joakimsen, R., Tsimtsiou, 
Z., \& Kiessling, C. (2021). What do we know about written assessment of health professionals' communication skills? A scoping review. Patient Education and Counseling, xxxx, 1-13. https://doi.org/10.1016/j.pec.2021.09.011.

Polat, Ö., \& Aydın, E. (2020). The Effect of Mind Mapping on Young Children's Critical Thinking Skills. Thinking Skills and Creativity, 38, 1-17. https://doi.org/10.1016/j.tsc.2020.100743.

Pramestika, N. P. D., Wulandari, I. G. A. A., \& Sujana, I. W. (2020). Enhancement of Mathematics Critical Thinking Skills through Problem Based Learning Assisted with Concrete Media. Journal of Education Technology, 4(3), 254. https: //doi.org/10.23887/jet.v4i3.25552.

Pratiwi, P. H. (2017). Pengembangan Modul Mata Kuliah Penilaian Pembelajaran Sosiologi Berorientasi HOTS. Cakrawala Pendidikan, 36(2), 201-209. https://doi.org/10.21831/cp.v36i2.13123.

Purnama, Y. I., \& Nurdianingsih, F. (2019). The Impact of Higher Order Thinking Skills (HOTS) Instructions in Teaching EFL Speaking Skill from the Perspective of Students' Motivation. Lingua Cultura, 13(4), 313. https://doi.org/10.21512/lc.v13i4.6105.

Purwasi, K. A., \& Fitiyana, N. (2020). Peningkatan Kemampuan Berpikir Tingkat Tinggi Siswa Melalui Pembelajaran Matematika Berbantuan LKPD Berbasis HOTS. Jurnal Pendidikan Matematika : Judika Education, 3(2), 65-74. https://doi.org/10.31539/judika.v3i2.1594.

Rahayu, S., Ladamay, I., Wiyono, B. B., Susanti, R. H., \& Purwito, N. R. (2021). Electronics Student Worksheet Based on Higher Order Thinking Skills for Grade IV Elementary School. International Journal of Elementary Education, 5(2), 453. https://doi.org/10.23887/ijee.v5i3.36518.

Rati, N. W., \& Rediani, N. N. (2020). E-learning Assissted by Finger Printing on Students' Critical Thinking and Creativity. Journal of Education Technology, 4(4), 433. https://doi.org/10.23887/jet.v4i4.30214.

Seibert, S. A. (2020). Problem-based learning: A strategy to foster generation Z's critical thinking and perseverance. Teaching and Learning in Nursing, 000, 2-5. https: //doi.org/10.1016/j.teln.2020.09.002.

Silberman, D., Carpenter, R., Takemoto, J. K., \& Coyne, L. (2021). The impact of team-based learning on the critical thinking skills of pharmacy students. Currents in Pharmacy Teaching and Learning, 13(2), 116-121. https://doi.org/10.1016/j.cptl.2020.09.008.

Sudira, P., \& Juwanto, R. E. (2019). Design training kits CPI for vocational learning in industry 4.0. International Journal of Recent Technology and Engineering, 8(3), 6293-6302. https://doi.org/10.35940/ijrte.C5917.098319.

Sumantri, M. S. (2015). Strategi Pembelajaran (1st ed.). Rajawali Pers.

Syudirman, \& Saputra, A. (2020). Konsep Higher Order Of Thinking Skill (Hots) Pada Pembelajaran Tematik Di SD/MI. Jurnal Pemikiran Dan Penelitian Pendidikan Dasar, 4(1), 133-143. https://doi.org/10.52266/el-muhbib.v4i2.557.

Widana, I. W. (2017). Modul Penyusunan Higher Order Thinking Skills (HOTS). Direktorat Pembinaan SMA, Direktorat Jenderal Pendidikan Dasar dan Menengah,Department Pendidikan dan Kebudayaan.

Wulandari, S., Hajidin, H., \& Duskri, M. (2020). Pengembangan Soal Higher Order Thinking Skills (HOTS) pada Materi Aljabar di Sekolah Menengah Pertama. Jurnal Didaktik Matematika, 7(2), 200-220. https://doi.org/10.24815/jdm.v7i2.17774.

Yu, Z., Hu, R., Ling, S., Zhuang, J., Chen, Y., Chen, M., \& Lin, Y. (2021). Effects of blended versus offline casecentred learning on the academic performance and critical thinking ability of undergraduate nursing students: A cluster randomised controlled trial. Nurse Education in Practice, 53(May), 103080. https://doi.org/10.1016/j.nepr.2021.103080. 